\title{
Coaching Pre-Service Teachers in Planning and Teaching English Online
}

\author{
Sitti Hadijah ${ }^{1 *}$ and Shalawati ${ }^{2}$ \\ ${ }^{12}$ English Language Education Department of Universitas Islam Riau, Pekanbaru, Riau, Indonesia \\ *Corresponding author. Email: sittihadijah@edu.uir.ac.id
}

\begin{abstract}
Before the outbreak of Covid 19, the pre-service teachers at the university where my colleague and I are teaching used to have a two-month teaching training session at schools to expand their knowledge, skill, and experiences in teaching face-to-face in the physical classroom. However, in this 2020/2021 academic year, the pre-service teachers' training program is arranged online and guided by teacher-educators. Through the online system, we found a great chance to train the pre-service teachers to plan and teach English online. Hence, this study investigates how the pre-service teachers plan and perform their online teaching during the coaching sessions. This study worked on a qualitative case study; the data were collected from the pre-service teachers' lesson plans, teaching practice videos, documentation of teaching activities in the Google Classroom. The findings reveal some issues encountered by the pre-service teachers in planning and performing their online teaching activities. Meanwhile, feedbacks from the teacher-educator help them to develop their skills in planning and managing online teaching.
\end{abstract}

Keywords: Pre-service teachers, planning in teaching, teaching English online

\section{INTRODUCTION}

Due to the outbreak of Covid-19 in Indonesia, the teaching and learning activities have been transformed from face-to-face learning in physical classrooms into online learning activities. This sudden transformation brings challenges for teachers and students. The teachers are challenged to deliver their teaching activities online and preparing online resources without receiving proper training [1]. Meanwhile, the students are also struggling to follow the online learning systems because of some factors; availability and sustainability of the internet connection, accessibility of teaching media, and compatibility of tools to access the learning media [2].

My colleague and I also experienced a difficult situation when firstly knowing that we had to teach online. Even though we have been using technology to support our teaching and learning activities daily, we still felt not ready to teach online. One significant matter that appeared in our mind was about how we could teach interestingly and effectively. Before applying the online learning system, we could foresee that one of the challenges in teaching online is how to engage the students in their learning. It is not low-hanging fruit in teaching, especially in an online classroom. Two-way interaction that could not be simply implemented in physical classrooms becomes more challenging in the online teaching [3].
To run online teaching effectively, teachers need to develop their pedagogical content knowledge skills (PCK). PCK relates to the teachers' ability to design and run meaningful online learning [4]. Regarding the PCK concept, my colleague and I took some professional development programs on online teaching as one of the ways out for our online teaching issues. We found that the programmes helped us better to prepare and run our online classes. In this case, participating in a training program of PCK skills is a need for teachers who need assistance in digital literary and managing online teaching effectively. Teachers' readiness to work on technology can bring positive outcomes for the students' achievements in their online education [4]. In addition, to figure out the challenges in teaching online, raising self-awareness on what action to take becomes necessary for teachers. The effort can bring positive values towards their professional performance as a teacher who not only shares information, but also needs to present dynamic, interesting, and interactive online learning [3].

However, not all of the teachers can reflect on their professional needs and take action to improve their teaching qualities. Influenced by internal and external factors, each teacher will take different reaction on facing a challenge in their teaching and learning process. Some of them will find ways to conquer their 
problems, while some others decide to ignore or put less effort to figure out their issues in teaching.

Looking at the teachers' reactions to their challenges in teaching online, preparing the pre-service teachers to be skilful in deploying technology in their teaching and learning process in the future is necessary. One of the most straightforward actions that my friend and I took when supervising a group of pre-service teachers in a teaching training program was coaching them to teach online. It was aimed to help the participants to be skilful in teaching online. They are expected not to have the same feeling as what my colleague and I experienced on our first-time task in teaching online.

Before the Covid 19 era, the pre-service teachers at the university where my colleague and I are teaching used to have a two-month teaching training session at schools to expand their knowledge, skill, and experiences in teaching face-to-face. The pre-service teachers have been familiar in face-to-face teaching activities because they had already experienced such learning activities when they were at schools and university. They also have received face-to-face teaching training when taking a micro-teaching subject.

Recently, the pre-service teachers' training program is arranged online and guided by the teachereducators. The pre-service teachers never received any training for teaching online even though they have learned the basic concepts of online learning and known some technologies to enhance the learning. Hence, this study aimed to investigate how the pre-service teachers plan and perform their online teaching during the coaching sessions.

\section{METHOD}

Working on a qualitative case study [5], investigating how the pre-service teachers plan and perform their online teaching during the online coaching sessions was the objective of this study. Eight preservice teachers from the educational faculty of English language education program were involved. They were taking online teaching practice training when this research was conducted. During the coaching sessions, the participants were assigned to plan and perform fourmeeting of online teaching activities.

The data were collected through documentation of the participants' lesson plans, teaching practice videos, and teaching activities in the Google Classroom. Before having the online teaching practices, the preservice teachers were assigned to select one topic that they would use for their teaching practice. The topics of the lessons were taken from a syllabus of teaching English at the tenth-grade of senior high school in Indonesia. Furthermore, the participants were assigned to plan their learning activities by writing lesson plans for teaching speaking, writing, reading, and listening skills.

In writing the lesson plans, the pre-service teachers had to concern on some components. They were learning objectives, learning indicators, learning materials, time allocation, teaching media, students' conditions, learning scenario, teaching method, assessment (task, scoring rubric, answer keys) which were adopted from a guide module of teaching practice, provided by the faculty.

After the pre-service teachers have completed their lesson plans, the teacher-educator checked their lesson plans' quality based on the components. Some revisions are required after receiving some feedbacks from the teacher-educator. The revised lessons plans were submitted online in the Google Classroom.

The pre-service teachers' performances in teaching online were managed into several ways; using Google Meet and Google Classroom. The participants were trained to use Google Meet for teaching speaking skill, while Google Classroom was used for teaching the other skills; writing, reading and listening. The participants' teaching performances were assessed based on some components; 1. Pre-learning activities (checking the classroom condition, tools, learning media, and students' readiness);2. Opening ( apperception and explaining the learning objectives); 3 . Main activities (mastering the taught lesson, integrating the lesson with other knowledge, presenting the lesson in organised, relating the lesson with the real-life condition); 4. Method (performing the lesson based on the students' characteristics, performing the lesson in order, organising the lesson well, applying contextual learning, relating the lesson with the local values/culture, encouraging good habits during the lesson, running the learning activities on time);5. The use of learning media/resources (skilfully in utilising the technology, providing an interesting message, effectively presenting the media, involving the students in the media used); 6. Performing discipline learning (engaging the students, giving positive responses, facilitating interaction between teacher and students, and among students, open for the students' responses, be connected with the students. Being Cheerful and enthusiastic in teaching); 7. Assessment (pre-test, observing the students' performances, giving practical tasks, evaluation); 8. Language use (fluent in speaking Engish, writing correctly in English, delivering the message appropriately); 9. Closing (reflection and feedback).

When working with the Google Meet, the preservice teachers' teaching and learning activities had to be run in 15-30 minutes length and documented in the 
form of video. Besides using Google Meet, the preservice teachers were also trained to teach virtually by using Google Classroom. The pre-service teachers have been familiar with the Google Classroom because they have used the platform in following some blended learning courses. However, the pre-service teachers had no experience as a teacher when using the Google Classroom. Hence, training in using Google Classroom was provided to expand the pre-service teachers' knowledge and experiences in teaching online.

Furthermore, the data were carefully reviewed, and significant codes representing the pre-service teachers' planning and performances in online teaching were identified. Data coding was done to reveal classification and emerging trends. Some changes in terms of grammar were intentionally done to present information clearly, without altering the meaning. Data coding was done independently by the researchers to validate the data, followed up by discussions to finalise the result.

\section{RESULTS}

The following information presents the preservice teachers' activities in planning and performing online teaching based on some aspects of planning and applying online teaching. The most representative extracts from the participants' responses are picked out. The collected data were labelled as "P", "LP", "TEN", meaning collected data from participants/pre-service teachers, lesson plans, and teacher-educator notes, respectively. The numbers put in the label represents the participant and document numbers, for example "P4" means that the data was taken from the fourth preservice teacher/participant, "LP1"shows data from the first lesson plan written by the participant, and "TEN 1" demonstrates the first note of the teacher-educator.

\subsection{Planning English Online Teaching}

When the pre-service teachers were working on their lesson plans, they had been familiar with all of the components of the lesson plan that they had to include in their lesson plans. The pre-services have included all of the criteria; learning objective, learning indicator, learning material, time allocation, teaching media, students' condition, learning scenario, teaching method, and assessment. However, some issues were found when the pre-service teachers had to describe each component. The issues were found in some components; learning objective, learning materials, teaching media, learning scenario, and assessment.

\subsubsection{Learning Objective}

The primary function of presenting learning objective in a lesson plan has not been fully aware by the pre-service teachers who followed the online teaching training. Some of the learning objectives that they put in their lesson plans were not suitable with the skills that they had to teach. When writing the lesson plans, the pre-service teachers just copied paste the information from the previous lesson plan that they had written. The table 1 presents some findings regarding the learning objective issues.

\section{Table 1. Issues in Setting Out the Learning Objectives}

\begin{tabular}{ll} 
Component & Description \\
\hline Learning & When writing a lesson for teaching \\
Objective & "writing skill", the pre-service teacher \\
& $\begin{array}{l}\text { stated the objectives of teaching } \\
\text { "speaking skill" (P1, LP2). }\end{array}$
\end{tabular}

When writing a lesson plan for teaching "reading skill", the pre-service teachers stated the objective of teaching "writing skill” (P5,P6, P7, LP3).

The findings present that the pre-service teachers need to know that writing a clear learning objective in eaching is essential, so it can improve their self-

awareness to always consider the learning objective when writing their lesson plans. During the coaching sessions, the teacher-educator had given some feedback about this issue. As a result, the learning objective issue was only found in one of the four lesson plans that had to be prepared by each participant.

\subsubsection{Learning Materials}

When analysing the pre-service teachers' lesson plans, some issues regarding the learning materials were also found. The findings could be seen in table 2. As previously explained that the pre-service teachers had to write four lesson plans for teaching a particular topic, taken from a syllabus of English teaching at senior high school in Indonesia. Based on the selected topic, the learning materials had to be prepared when the preservice teachers were preparing their lesson plans. However, in some of the participants' lesson plans, the learning materials were not presented in detail, they just put general information that was not really effective to support the teaching and learning activities; by giving detail information about the learning materials in the lesson plan, it can help the pre-service teachers or teachers to present the lesson to the students effectively without spending time to look for the materials in the books or other sources. 
Table 2. Issues in Preparing Learning Material

\begin{tabular}{|l|l|}
\hline Component & Description \\
\hline Mearning & $\begin{array}{l}\text { Not presented in the lesson plan } \\
(\mathrm{P} 1, \mathrm{LP} 1)\end{array}$ \\
\cline { 2 - 2 } & Too general (P1, LP2) \\
\cline { 2 - 2 } & Too general (P1, LP3) \\
\cline { 2 - 2 } & Too general (P1, LP4) \\
\cline { 2 - 2 } & Too General (P2, LP2) \\
\cline { 2 - 2 } & $\begin{array}{l}\text { Not presented in detail/ very short (P4, } \\
\text { LP1) }\end{array}$ \\
\cline { 2 - 2 } & Not clearly presented (P5, LP3) \\
\cline { 2 - 2 } & Too general (P5, LP4) \\
\cline { 2 - 2 } & Too general, not detail (P6, LP1) \\
\cline { 2 - 2 } & Not detail (P7, LP3) \\
\cline { 2 - 2 } & Too general (P8, LP3) \\
\hline
\end{tabular}

\subsubsection{Teaching Media}

In term of teaching media planed by the preservice teachers for their online teaching, the pre-service teachers planned to use several media to support their teaching process, and they were; PowerPoint Slides, videos, pictures, and audios to present the lessons. The selected media were not attached to their lesson plans. All of the participants only stated that they would use the media for their online teaching activities. However, the learning media could not be found in their lesson plan's attachment. This matter could show that the participants have not prepared the learning media when finishing their lesson plans.

Table 3. Issues in Preparing Teaching Media

\begin{tabular}{|l|l|}
\hline Component & Description \\
\hline Teaching Media & $\begin{array}{l}\text { The media or its example could } \\
\text { not be found (Video/Google } \\
\text { Classroom/Kahoot (P1, LP2) }\end{array}$ \\
\cline { 2 - 2 } & $\begin{array}{l}\text { Video, pictures, ppt (Not } \\
\text { attached) (P4, LP1) }\end{array}$ \\
\cline { 2 - 2 } & $\begin{array}{l}\text { PPT/Gambar/Video (Not found } \\
\text { in the lesson plan) (P6, LP1) }\end{array}$ \\
\hline
\end{tabular}

\subsubsection{Learning Scenario}

After analysing the lesson plans of the preservice teachers, there were some activities of the learning scenario arranged which were not suitable to be implemented for online teaching and learning activities. Some of the planned activities were more suitable for teaching in physical classroom activities. The following findings were found in the participants' lesson plans for teaching speaking skill.
Table 4. Issues in Arranging Learning Scenario

\begin{tabular}{|l|l|}
\hline Component & Description \\
\hline Learning Scenario & "Siswa mencari cara memberi \\
& dan menerima ucapan selamat \\
& dari sumber lain, baik dari buku \\
& maupun internet." (P4, LP1) \\
(The students find out the \\
expressions of giving and \\
accepting congratulation from \\
various sources, such as books \\
and the internet). \\
\hline
\end{tabular}

The above activity was written by one of the preservice teacher's main activities in teaching speaking skill of expressions of compliment. It was not an effective activity for online teaching because both the teacher and students have limited time for online learning activities. It is better to previously assign the students to find out the learning materials before coming into the online classroom. In other words, online learning activities can be optimised by checking the students' understanding or guiding students to have a better understanding of what they have leant before.

The other findings can be seen in the following table

Table 4a. Issues in Arranging Learning Scenario

\begin{tabular}{|c|c|}
\hline Component & Description \\
\hline \multirow[t]{4}{*}{$\begin{array}{l}\text { Learning } \\
\text { Scenario }\end{array}$} & $\begin{array}{l}\text { "Melalui berbagai situasi yang diberikan } \\
\text { oleh guru, siswa diminta untuk maju } \\
\text { kedepan bersama teman kelompok mereka } \\
\text { untuk mempraktekkan percakapan yang } \\
\text { berkaitan dengan memberi dan menerima } \\
\text { ucapan selamat." (P3, LPI) } \\
\text { (The students were invited to practice the } \\
\text { lesson in front of the class). }\end{array}$ \\
\hline & $\begin{array}{l}\text { "Guru menunjuk siswa untuk maju ke } \\
\text { depan kelas dengan semangat dan santun." } \\
\text { (P5, LP1) } \\
\text { (The teacher invited the students to stand in } \\
\text { front of the class for speaking practice). }\end{array}$ \\
\hline & $\begin{array}{l}\text { "Guru meminta siswa untuk menampilkan } \\
\text { percakapan yang sudah dibuat kedepan } \\
\text { kelas dengan teman sebangku." (P6, LP1) } \\
\text { (The teacher invited the students to perform } \\
\text { a prepared dialogue in front of the class). }\end{array}$ \\
\hline & $\begin{array}{l}\text { "Guru meminta siswa untuk memaparkan } \\
\text { jati dirinya didepan kelas secara individu." } \\
\text { (The students introduced themselves in } \\
\text { front of the class) }\end{array}$ \\
\hline
\end{tabular}

The findings present that the students were invited to practice the lessons in front of the class. This planned activity was not in line with the procedure of online teaching because the students cannot perform the learning activities in front of the class, they can only 
practise the language in front of their laptop or smartphone. It can be seen clearly that the pre-service teachers did not fully aware that the planned learning activities have to refer to the online teaching activities. In planning the lesson plans, the pre-service teachers planned to use and play a video during the teaching and learning activities. The planned activities are listed below:

Table 4b. Issues in Arranging Learning Scenario

\begin{tabular}{|l|l|}
\hline Component & Description \\
\hline Learning & "Guru memutar video tentang intention." \\
& $(P 4$, LP1) \\
& (The teacher plays a video) \\
\cline { 2 - 2 } & "Guru menampilkan video tentan \\
& describing place terlebih dahulu." \\
& (The teacher plays a video) $(P 3$, LP1) \\
\cline { 2 - 2 } & "Guru menampilkan video tentan \\
& describing place terlebih dahulu." \\
& (The teacher presents a video) $(P 4$, LP1) \\
\cline { 2 - 2 } & "Guru menayangkan video percakapan \\
& tentang pemaparan jati diri." (P1, LP1) \\
& (The teacher presents a video) \\
\hline
\end{tabular}

The pre-service teachers should not plan to play the videos during their online teaching activities because they need to consider the students' internet access that can affect the effectiveness of the video use. It is better for the pre-service teachers to send the learning video before the scheduled meeting, so the students can learn the video asynchronously. Assigning the students to watch the video before coming into the class can help the pre-service teacher and students to maximise the online session to practice the language communicatively by discussing the video that the students had watched.

\subsubsection{Assessment}

Some issues in assessments were also found. The detailed description of the issues could be seen in the following table.

Table 5. Issues in Assessment

\begin{tabular}{|l|l|}
\hline Component & Description \\
\hline Assessment & $\begin{array}{l}\text { No test prepared, but the speaking scoring } \\
\text { rubric could be found( P1, LP1). }\end{array}$ \\
\cline { 2 - 2 } & No test prepared (P1,P2,P5, LP2, LP3,LP4) \\
\cline { 2 - 2 } & The test was not found (P3, LP1) \\
\cline { 2 - 2 } & $\begin{array}{l}\text { The test provided, but it was not suitable to } \\
\text { assess the students' reading skill (P3, LP3) }\end{array}$ \\
\cline { 2 - 2 } & $\begin{array}{l}\text { The test was not prepared, but the rubric } \\
\text { could be found (P4,P5, LP1) }\end{array}$ \\
\cline { 2 - 2 } & $\begin{array}{l}\text { The test was not found, only the rubric ( } \\
\text { P7, LP3) }\end{array}$ \\
\hline
\end{tabular}

In composing the lesson plans, most of the preservice teacher could not describe clearly the assessment component of their lesson plans. This matter appears because the pre-service teacher did not provide a task that the students had to complete during or after the learning activities. Some students just described the scoring rubric of the task, while the form of the task could not be found in the lesson plan. This is one of the essential issues because the task that should be prepared by the pre-service teachers has function as an instrument to measure how well the students could accept or understand the lesson. Besides that, some other preservice teachers did not provide appropriate tasks for the students. In other words, the given task was not suitable for the skills that the students had to learn during the online session. Some feedbacks were provided by the teacher-educator when finding the pre-service teachers' issue in the assessment.

\subsection{Teaching English Online}

In relation to the online teaching activities performed by the pre-service teachers in the coaching sessions, they had shown their best efforts to complete all of the online teaching activities; teaching speaking skill by using Google Meet, and teaching writing, reading, and listening skills by using Google Classroom. After analysing the pre-service teachers' performances in their online teaching, the pre-service teachers faced hindrances in performing some indicators in their online teaching practices. The issues experienced by the preservice teachers were documented by the teachereducator with TEN.

\subsubsection{Main activities}

There are two issues related to the pre-service teacher's performances while teaching speaking, writing, reading, and listening skills. The pre-service teachers need to improve their knowledge about the contents that they had to teach. "The learning materials presented by the pre-service teachers were not challenging enough for the students. They contain more conceptual information, while the students highly need practical content that can stimulate them to practice English communicatively (TEN 1)." Besides that, "the pre-service teachers only focused on teaching the content; they could not integrate the content with other related knowledge and real-life condition that can improve the students' participation (TEN2)."

\subsubsection{The use of learning media/resources}

In using the learning media, the pre-service teachers could work well with the prepared media and learning platforms, but their skills to effectively present the learning media need to be improved. "The media 
could be well by the pre-service teachers; they used PowerPoint slides, images, audios, and videos to deliver their lessons, but the pre-service teachers' performances in presenting the media need to be improved. They should be able to encourage the students to pay attention to the learning media by providing challenging questions/exercises that can increase their curiosity on the lesson (TEN 3). Also, "when presenting the learning media, the pre-service teachers need to stimulate the students to have their critical thinking by providing creative, interactive, and informative resources (TEN 4)." Furthermore, "the pre-service teachers did not have rich resources for their teaching, so the information in the learning media just refer to very limited content to practice the language (TEN 5)." In other words, it is clear that the pre-service teachers still need to develop their skills in using learning media/resources.

\subsubsection{Performing discipline learning}

There were three issues found about the preservice teachers' performances in this component (performing discipline learning); lack of students' engagement, lack of interaction among teacher and students, and lack of cheerfulness and enthusiasm in teaching. "The pre-service teachers need to improve their skills in engaging the students during online learning. Engagement became one of the issues because the pre-service teachers have not fully understood how to engage the students. This issue was found because the pre-service teachers were busy on explaining the content in the PowerPoint slides that they had prepared(TEN $6)$. ." Then, "interaction among pre-service teachers and other students rarely happen during the online practice (TEN 7). Furthermore, "the pre-service teachers did not show cheerfulness and enthusiasm in their learning because they looked intimidated and had flat intonation when explaining the lesson to the students (TEN 8). All of the issues found in this component revealed that the pre-service teachers need to develop their social and personal skills in teaching online.

\subsubsection{Assessment}

In assessment aspect, giving suitable tasks, and evaluation were still found as issues for the pre-service teachers during their online teaching practice. "Unsuitable tasks for teaching reading skills were found (TEN 9)." The pre-service teachers did not integrate the skill that they were teaching with the test that they had to give to the students. The pre-service teachers need to be guided on how to construct a suitable test for assessing each language skill.

\subsubsection{Language Use}

These are the pre-service teachers' issues in term of language use in their online teaching performances:

"Not all of the pre-service teachers have fluent English when they did their online teaching practice (TEN 10)."

"Some grammatical problems were also found when they present the lesson in their learning media and some questions in the task (TEN 11)."

"Some of the pre-service teachers did not communicatively explain the lesson (TEN 12)."

All of the findings in the pre-service teachers' language skill demonstrate that language barriers also affect their performance in teaching English online. They failed to perform live learning environment because they could not effectively express the language.

\subsubsection{Closing}

Since the limited time for performing the online teaching, reflection and feedback were not found in the last section of the pre-service teaching. "The pre-service teachers just closed the class by giving summary and tasks for the students (TEN 13).

\section{DISCUSSION}

This article aimed to present how the pre-service teachers plan and perform their online teaching during the coaching sessions. In planning the online teaching, the pre-service teachers have not fully understood how to set up the learning objectives, materials, teaching media, learning scenario, and assessment. All of the issues experienced by the pre-service teachers are core elements that can affect the quality of the teaching if they are not well prepared. By preparing for performing online teaching can be an effective way to present online learning [6]. In a previous study, the researchers found that a group of English teachers did not run their online teaching effectively because of lack of preparation and planning to teach online [7]. The teachers must learn how to prepare and run online teaching effectively [8]. They have to be creative to find out the best ways that they can take to improve their skills in teaching online.

As in the preparation of traditional teaching, setting out the learning objective is also one of the main components in online teaching. By understanding the learning objectives, the learning activities could be well managed because it can affect the effectiveness of the learning system [9].

In addition, the teacher also needs to prepare online learning materials comprehensively to cover the requirements of the syllabus and show them through the integration of technology [10]. Preparing online learning materials is not a simple task to do. Pre-service and in- 
service teachers need to train themselves for that purpose. The learning materials in online learning can be presented by using texts, images, audios, videos, or social media platforms that can facilitate the students to get information independently and also communicate it effectively.

Furthermore, preparing teaching media was also challenging for the pre-service teachers because they did not only need to be skilful in utilising the learning platforms to perform their online teaching, such as Google Meet and Google Classroom, but they also need to choose friendly platforms, such as WhatsAPP [2], and some other tools to present the lessons effectively, such as digital language learning applications, games, and videos [11].

The use of teaching media cannot be separated from the learning scenario that has to be arranged well. Teachers' creativity in managing effective online learning scenario is also essential. The learning activities should be able to encourage the students to participate actively during the learning process and have experiences to practice the language communicatively. In online learning activities, the learning scenario should be arranged to encourage the students to feel learning in the real-live environment. The learning activities can be arranged in synchronous or asynchronous modes [7].

In term of preparing an online assessment, the pre-service teachers need guidance on how to construct the best instruments to assess particular language skill. Applications to support online assessment should be introduced to the pre-service teachers, for example, Kahoot. In a literature review study, Kahoot was found as one of the applications that was used to assess students' learning performance [12].

Meanwhile, in performing the online teaching practices, the pre-service teachers need to improve their performances in running the main activities, using learning media/resources, performing discipline learning, doing an assessment, using communicative language, and closing the class properly.

When presenting main activities in online teaching, the pre-service teachers need to provide more challenging contents that do not only can expand the students' knowledge, but also develop their critical thinking and language skills. In this case, synchronous online discussion can be a method that can be applied in online teaching. Synchronous discussion was found as good online teaching mode that can facilitate more interaction between teacher and students [13]. Then, the effectiveness of performing the learning activities are also affected by the learning media or digital resources. Based on a study in Indonesia that was investigating the uses of digital application in teaching and communicating with the students' parents, the percentages for the application uses are fairly high because the teachers have been working with various teaching applications, such as Zoom/Google Meet, WhatsApp, Google Classroom [14]. However, providing professional development program on the technology-enhanced learning still requires by the preservice and in-service teachers due to the needs of presenting innovative learning atmosphere.

In performing discipline learning, the pre-service teachers also need improvement on this component because the discipline learning faced by the pre-service teachers relate to their performance in engaging, interacting, and showing cheerfulness and enthusiasm in teaching. To make the online learning engaging, interactive, and effective; using smart tools, involving the students in creating learning resources, organising students' e-learning cycle, open discussion forum, and suggesting MOOC (Massive Open Online Courses) for students are some solutions that should be followed [8].

In giving assessment, it is one of the challenging parts in online teaching activities, especially in giving tasks and monitoring the students' activities in completing the task honestly [4]. Providing training on how to assess online learning activities becomes necessary for the pre-service teachers because they still have limited knowledge on this aspect. It is suggested for the pre-service and in-service teachers to know effective assessment application that can be effectively given to the students and ease the teachers' efforts in designing, monitoring and checking the tasks for the students. In addition, providing a concrete task that can facilitate the students to work collaboratively should be included in online assessment, [15].

The pre-service teachers also need to have better communication skills in verbal or written communication modes. The explanation and instruction have to be given clearly to avoid misunderstanding[15], especially in giving task. The pre-service and in-service teachers need to be guided to deliver the information in simple manners, such as using high-frequency words, simple sentence constructions, and clear pronunciation. Opening extra communication channels can be a solution to help the students in getting clear information and avoiding misunderstanding and demotivating in their learning activities. Besides that, the pre-service and in-service teachers should be guided to have a reflection on their online teaching by asking for the students' feedback or perspectives.

\section{CONCLUSION}

Great teaching is always great teaching, whether it is applied in physical classrooms of virtual classrooms. The teachers need to plan their teaching 
activities to successfully create a good teaching atmosphere. To be skillful in teaching, particularly in online teaching, is not low hanging fruit, the teachers and pre-service teachers need to prepare themselves by taking some efforts, such as following self-development programs or training/coaching sessions. Providing training for pre-service and in-service teachers can be a solution to improve the quality of their online teaching. Furthermore, the pedagogical implication of this study relates to the issues experienced by the pre-service teachers in preparing and teaching English online reveal that there is also a need to provide additional training subjects for teaching English online. It could be a great effort to prepare the next generation of teachers to be professional teachers who are able to perform their teaching activities in any situation, whether it is in online teaching or physical classroom activities. Teacher-educators have essential roles in guiding the pre-service teachers and in-service teachers to perform their teaching interestingly, effectively, and innovatively.

\section{REFERENCES}

[1] P. D. MacIntyre, T. Gregersen, and S. Mercer, "Language teachers' coping strategies during the Covid-19 conversion to online teaching: Correlations with stress, wellbeing and negative emotions," System, vol. 94, p. 102352, 2020, doi: 10.1016/j.system.2020.102352.

[2] A. S. N. Agung and M. W. Surtikanti, "Students' Perception of Online Learning during COVID-19 Pandemic: A Case Study on the English Students of STKIP Pamane Talino," SOSHUM J. Sos. dan Hum., vol. 10, no. 2, pp. 225-235, 2020, doi: 10.31940/soshum.v10i2.1316.

[3] S. Dhawan, "Online Learning: A Panacea in the Time of COVID-19 Crisis," J. Educ. Technol. Syst., vol. 49, no. 1, pp. 5-22, 2020, doi: $10.1177 / 0047239520934018$.

[4] T. Volery and D. Lord, "Critical success factors in online education," Int. J. Educ. Manag., vol. 14, no. 5, pp. 216-223, 2000, doi: 10.1108/09513540010344731.

[5] J. W. Cresswell, Educational Reseach Planning, Conducting and Evaluating Quantitative and Qualitative Research, Fourth Edi. Pearson, 2012.

[6] L. V Popova and M. M. Pikulenko, "Teacher' s Readiness to Create Own Online Courses," vol. 2020, pp. 2017-2031, 2020, doi: 10.3897/ap.2.e2017.

[7] A. E. P. Atmojo and A. Nugroho, "EFL Classes Must Go Online! Teaching Activities and Challenges during COVID-19 Pandemic in Indonesia," Regist. J., vol. 13, no. 1, pp. 49-76,
2020, doi: 10.18326/rgt.v13i1.49-76.

[8] Z. Zayapragassarazan, "COVID-19: Strategies for Online Engagement of Remote Learners," F1000Research, no. April, 2020, doi: 10.7490/F1000RESEARCH.1117835.1.

[9] N. Peachey, "MANAGING ONLINE LEARNING 1. What is it?" Oxford University Press, pp. 1-5, [Online]. Available: www.oup.com/elt/expert.

[10] P. T. Febrianto, S. Mas'udah, and L. A. Megasari, "Implementation of online learning during the covid-19 pandemic on Madura Island, Indonesia," Int. J. Learn. Teach. Educ. Res., vol. 19, no. 8, pp. 233-254, 2020, doi: 10.26803/ijlter.19.8.13.

[11] N. Hockly, "Teaching online." Oxford University Press, pp. 1-5, 2020.

[12] A. I. Wang and R. Tahir, "The effect of using Kahoot! for learning - A literature review," Comput. Educ., vol. 149, no. January, 2020, doi: 10.1016/j.compedu.2020.103818.

[13] A. B. Rinekso and A. B. Muslim, "Synchronous online discussion: teaching English in higher education amidst the covid-19 pandemic," JEES (Journal English Educ. Soc., vol. 5, no. 2, pp. 155162, 2020, doi: 10.21070/jees.v5i2.646.

[14] U. Alifia, A. R. Barasa, L. Bima, R. P. Pramana, S. Revina, and F. A. Tresnatri, "Learning from Home: Portrait of Teaching and Learning Inequalities in Times of The Covid-19 Pandemic,' Smeru Res. Note, vol. 1, no. 1, pp. 1-8, 2020.

[15] C. Rapanta, L. Botturi, P. Goodyear, L. Guàrdia, and M. Koole, "Online University Teaching During and After the Covid-19 Crisis: Refocusing Teacher Presence and Learning Activity," Postdigital Sci. Educ., vol. 2, no. 3, pp. 923-945, 2020, doi: 10.1007/s42438-020-00155-y. 